\title{
MAZURZY NA PODOLU WSCHODNIM: PAMIEĆ́, TOŻSAMOŚĆ I DZIEDZICTWO
}

\author{
MASURIANS IN THE EAST PODOLIA: MEMORY, \\ IDENTITY AND HERITAGE
}

\begin{abstract}
The theme of this article is specific identity and memory of the Polish population in the selected villages of Khmelnytskyi Raion of Ukraine, with the second most numerous Polish population in Ukraine. The specificity of this Polish population results from a long habitation in the same territory. From the moment they arrived on Podolia until their deportations to Kazakhstan and Siberia in the 1930s, this group did not migrate at all. The article is based on research conducted in three the so-called "Masurian" villages. The inhabitants of these areas are defined as Masurians - they are descendants of Polish peasants who settled therein the seventeenth and eighteenth centuries. The text shows the identity of the ethnic community of "Masurian" villages and the memory of their Polish peasant roots. Hundreds years of living together in one region and endogamy rules in force since the Second World War have contributed to the fact that these local communities have preserved memory of their Polish and peasant origin, as well as their specific dialect and religion.
\end{abstract}

Key words: East Podolia; Ukraine; Masurians; memory; heritage; community; identity

\section{Streszczenie}

Tematem artykułu jest specyfika tożsamości i pamięci ludności polskiej w wybranych wsiach obwodu chmielnickiego na Ukrainie, który jest drugim co do liczebności polskiej ludności
MARCELINA JAKIMOWICZ Uniwersytet Wrocławski, Wrocław E-mail: marcelina.jakimowicz@gmail.com

CITATION: Jakimowicz, M. (2017). Mazurzy na Podolu Wschodnim: pamięć, tożsamość i dziedzictwo. Sprawy Narodowościowe. Seria nowa, 2017(49). https://doi.org/10.11649/sn.1210

This work was supported by the author's own resources. No competing interests have been declared.

This is an Open Access article distributed under the terms of the Creative Commons Attribution 3.0 PL License (creativecommons.org/licenses/by/3.0/pl/), which permits redistribution, commercial and non-commercial, provided that the article is properly cited. (C) The Author(s) 2017.

Publisher: Institute of Slavic Studies, Polish Academy of Sciences 
obwodem Ukrainy. Specyfika ludności polskiej na terenie prawobrzeżnej Ukrainy opiera się na jej długim trwaniu na jednym terytorium. Od chwili przybycia na teren Podola aż do momentu zsyłek do Kazachstanu i na Syberię w latach 30. XX wieku tej grupy nie dotykały ruchy migracyjne. Artykuł opiera się na badaniach prowadzonych w trzech wsiach zwanych „mazurskimi”: Hreczanach, Szaraweczce i Maćkowcach. Ludność zamieszkująca te tereny określa się mianem Mazurów - potomków polskich chłopów, osadników z XVII i XVIII wieku. W tekście przedstawiono charakter tożsamości ludności wsi mazurskich, pamięć wspólnotową dotyczącą polskich i zarazem chłopskich korzeni grupy. Kilkusetletnie życie w jednym regionie, jak i obowiązująca do czasów II wojny światowej zasada endogamii spowodowały, że wspólnoty wsi mazurskich zachowały pamięć o swoim polskim i zarazem chłopskim pochodzeniu, gwarę i wyznanie.

Słowa kluczowe: Podole Wschodnie; Ukraina; Mazurzy; pamięć; dziedzictwo; wspólnota; tożsamość

W ogóle włościanie-katolicy lubią tu mówić po polsku i w stosunkach z wyższymi i oświeceńszymi klasami społecznymi używają zwykle polskiego języka, choćby nawet nim słabo władali. Ku granicy austryjackiej, np. w powiecie proskurowskim (...) są całe wsie i parafie nawet, w których językiem potocznym włościan katolików jest polski i to wcale poprawny.

(Kolberg, 1994, s. 18)

\section{WPROWADZENIE}

ak pisze Magdalena Zowczak, o ile istnieje dość bogata literatura opisująca życie podolskiej wsi, o tyle niewiele napisano o "Mazurach"1. Nazwa ta pojawiła się w literaturze w XIX wieku niekiedy jako etnonim, który wskazywał Mazowsze jako teren ich przybycia, z drugiej strony określano ich jako włościan katolików (Zowczak, 2004, s. 223). Specyfika Polaków autochtonów „za Zbruczem” polegała na tym, że od etapu osadnictwa do zsyłek do Kazachstanu i na Syberię w latach 30. XX wieku nie obejmowały ich procesy migracyjne (Iwanow, 2014, ss. 39-40). W tym kontekście są niezwykle ciekawą wspólnotą pamięci, która od ponad 300 lat powiązana jest z terenem Podola. Stanowią specyficzną grupę opierającą się na świadomości historycznej i pamięci o chłopskich, ale zarazem polskich korzeniach. Pamięć społeczności „mazurskich wsi” Podola Wschodniego jest interesująca, ponieważ na jej kształt wpływ miały także tragiczne wydarzenia na Ukrainie radzieckiej, które dotknęły grupę w XX wieku: represje, zsyłki, Wielki Głód na Ukrainie w 1933 roku, II wojna światowa i powojenna walka władz radzieckich z religijnoś-

\section{- $\cdots \cdots$}

Artykuł jest pokłosiem prowadzonych w lipcu i sierpniu 2015 roku badań na terenie trzech wsi obwodu chmielnickiego na Ukrainie: Hreczanach (ukr. Гречани), Маćkowcach (ukr. Мацьківці) i Szaraweczce (ukr. Шаровечка). Etnograficzne badania terenowe finansowane były z grantu wewnętrznego Wydziału Nauk Historycznych i Pedagogicznych Uniwersytetu Wrocławskiego. Projekt badawczy nr 1315/M/KEAK/15 pt. Mazurzy na Podolu - dziedzictwo, tożsamość i pamięć. Technikami badawczymi były wywiad pogłębiony, wywiad biograficzny z najstarszym pokoleniem, ale także obserwacja uczestnicząca. Najwięcej czasu spędziłam we wsi Maćkowce, ogromne znaczenie dla badań miał fakt, że prowadziłam je w miejscu zamieszkania mojej dalszej rodziny, co wpłynęło na relację między mną a rozmówcami. Przedmiotem badań była specyfika tożsamości i pamięci ludności polskiej w wybranych mazurskich wsiach. W czasie prowadzenia badań rozmawiałam z kilkudziesięcioma mieszkańcami wsi, ale także mieszkałam we wsi Maćkowce, co pozwoliło mi na częstszy i lepszy kontakt z rozmówcami. 
cią lokalnej ludności. Te doświadczenia mają wielki wpływ na samoidentyfikację Polaków zamieszkujących dawne tereny ukraińskiej SRR. Mieszkańcy wsi Podola Wschodniego do dzisiejszego dnia określają się jako Mazurzy. W artykule skupiam się na ludności wsi zwanych mazurskimi, które znajdują się w okolicach miasta Chmielnickie (do 1954 roku Proskirów, ukr. Хмельницький). Ludność mazurskich wsi w domu używa południowo-wschodniej odmiany polskiego dialektu kresowego ${ }^{2}$ oraz miejscowego dialektu ukraińskiego, ich gwara jest mieszanką polonizmów, rusycyzmów i ukrainizmów (Werenicz, 1996, s. 126).

Pokrótce przestawię, w jaki sposób przeszłość zarówno ta najodleglejsza, jak i ta najnowsza - związana z tragicznymi wydarzeniami XX wieku - wpływa na tożsamość mieszkańców wsi zwanych mazurskimi na Podolu Wschodnim. Rozpoczynając od teoretycznego wprowadzenia, przechodzę do krótkiego zarysu historii migracji lokalnej ludności wsi mazurskich na teren Podola. Następnie przedstawiam sytuację polskiej ludności w okresie międzywojennym w ukraińskiej SRR - celowo skupiam się na tym okresie, szczególnie na latach 30. XX wieku, w którym rozpoczęły się represje wobec mniejszości narodowych i etnicznych ZSSR, ponieważ te wydarzenia, jak i Wielki Gtód na Ukrainie dominowały w narracjach rozmówców. Następnie przechodzę do opisu przykładu pamięci wspólnoty jednej z "mazurskich wsi” - Maćkowiec (ukr. Мацьківці) W okolicach miasta Chmielnickie. W artykule przedstawiam, w jaki sposób pamięć o chłopskich korzeniach, jak i wpływ tragicznych wydarzeń wielkiej historii XX wieku wpłynęły na tożsamość Mazurów zamieszkałych na terenie Podola Wschodniego.

\section{INSPIRACJE TEORETYCZNE}

Każda grupa społeczna ma własną tradycję, dziedzictwo, przeszłość, każda ma też własne sposoby transmisji tych wartości. Dziedzictwo definiuję za Jerzym Szackim jako mniej lub bardziej spójny zespół wzorów zachowań, od pokoleń właściwy grupie, czyli te elementy z przeszłości wspólnoty, które są przekazywane kolejnym pokoleniom (Szacki, 2011, s. 132). Każda grupa społeczna poprzez własny język, pismo, znaczenia przypisywane rodzinie przekazuje w obrębie pokoleń pamięć o ważnych dla niej wydarzeniach, jak i wartościach, które decydują o charakterze i poczuciu jedności wspólnoty (Szacki, 2011, s. 114). Tożsamość grupy jest kontynuacją, czy też zachowaniem jej charakteru w czasie. Człowiek należy do danej społeczności, gdy jest w stanie przyswoić sobie normy otoczenia - może wtedy osiągnąć przynależne tożsamości: stabilność i przewidywalność (Assmann, 2013, s. 147). Bliskie mi są także słowa Bronisława Malinowskiego, który pisał, że „praktyczne zadanie antropologa polega na wykryciu ile jeszcze pozostało z danej instytucji (...). Chodzi tu głównie o to, że interesuje nas żywotność i obecna działalność tych instytucji, a nie działanie w jakimkolwiek okresie przeszłości" (Malinowski, 1958, ss. 159-161). Na przykładzie wspólnot wsi mazurskich Podola Wschodniego i ich pamięci skupiam się na tych wydarzeniach, elementach przyszłości, którym rozmówcy poświęcali najwięcej uwagi w rozmowach.

Z perspektywy pamięci wspólnotowej Mazurów nie interesuje mnie tylko ich historia, choć ta, szczególnie dotycząca represji i lat wojennych ma ogromne znaczenie dla wspól-

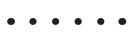

2 Władysław Werenicz zwraca uwagę, że specyfiką tego chłopskiego prostego języka jest mazurzenie, samogłoski ścieśnione, tzw. wałkowane "ł" oraz inne, występujące w gwarach etnicznie polskich, lecz obce polszczyźnie miejscowej inteligencji, jak i południowo-wschodniemu dialektowi kresowemu miejscowej polskiej szlachty. 
noty wsi. Przede wszystkim ciekawiła mnie pamięć o tych tragicznych wydarzeniach, a także pamięć o korzeniach grupy, czyli wpływ przeszłości na pamięć i tożsamość lokalnej ludności. Przez wieki z powodu pewnego zamknięcia i długiego trwania w jednym miejscu mieszkańcy mazurskich wsi okolic Chmielnickiego stanowią wspólnotę niezwykle zasklepioną ${ }^{3}$.

Wspólnotę charakteryzuję za Ferdinandem Tönniesem, jako grupę opartą na wspólnej woli, tradycji, naturalnych więziach (często pokrewieństwa) i wspólnym terytorium. Wspólnotę cechuje także pewna bliskość duchowa, poczucie jedności i wiary we wspólne pochodzenie (Tönnies, 2008, s. 43). Mazurzy, zachowujący poczucie jedności duchowej i pamięć o przybyciu na te ziemie z terenów etnicznie polskich, mogą być przykładem wspólnoty pamięci, która opiera się na wspólnej przeszłości grupy, a także wiary we wspólne korzenie.

W pamięci Polaków na terenie rejonu chmielnickiego należącego dawniej do terenów sowieckiej Ukrainy najmocniej odznaczyły się wydarzenia z XX wieku, które wiążą się z eksterminacją grupy, łącząc przy tym jej losy z ukraińskimi mieszkańcami tych ziem. Wiek XX jest okresem najlepiej zapamiętanym przez rozmówców i mającym największe znaczenie, nie tylko z perspektywy krótkiego czasu od wydarzeń z przeszłości ale także tragicznego charakteru tych doświadczeń i ich powszechności. Pewne fragmenty historii tych ziem, w szczególności stosunek sowieckich władz wobec mniejszości narodowych i etnicznych w latach 1920-1930. są pewnym rodzajem przeciw-pamięci, która za Foucault jest definiowana jako dyskurs pamięci alternatywnej wobec dominujących. Przeciw-pamięć rozbija uniwersalny charakter historii, opiera się na doświadczeniach grup dotychczas przez „wielką historię" nie dostrzeganych: mniejszościach etnicznych, religijnych czy seksualnych:

Przeciw-pamięć wyłania się jako głos wypędzonych z głównego nurtu pamięci: zapomnianych, zwyciężonych, niewielkich. (...) Ich wiedza o przeszłości ma charakter fragmentaryczny, często kwestionowany pod zarzutem nieadekwatności czy wręcz naiwności. Przeciw-pamięć jako nieuprzywilejowaną, niefaworyzowaną formą wiedzy o przeszłości. Służy właśnie [tym wyobcowanym, zapomnianym grupom], odpowiadając na ich potrzebę powołania do życia takich form ekspresji, w których będą mogli wyrazić własne doświadczenia przeszłości (Saryusz-Wolska \& Traba, 2014, s. 400).

Represje wobec mniejszości narodowych i etnicznych na terenie radzieckiej Ukrainy można traktować także jako etniczną przeciw-pamięć wobec pamięci narodowej polskiej, są one odległe od głównego nurtu pamięci opartej w większości na wydarzeniach dziejących się co najwyżej w przedwojennej II Rzeczypospolitej. Z drugiej strony pamięć o represjach lat 30., czasach wielkiego głodu na Ukrainie i pamięć o II wojnie światowej powoduje, że część wydarzeń z historii społeczności wsi mazurskich zawiera się w pamięci narodowej - ukraińskiej. Interesuje mnie pamięć potoczna, ta która przekazywana jest w ramach wspólnoty, rodzin czy wsi, „to co myślą i jak te swoje myślenie okazują światu zewnętrznemu zwykli ludzie, nie (tylko) elity" (Wylęgała, 2015, s. 100). Dlatego skupię się na wybranych fragmentach pamięci wsi określanych mianem „mazurskich" - tych wydarzeniach z historii, które dla samych rozmówców wydawały się ważne, którym poświęcali najwięcej czasu w rozmowach.

3 Mimo że dziś prawie połowa mieszkańców wsi: Maćkowce, Hreczany i Szaraweczka, które znajdują się w pobliżu miasta bądź jak Greczany są już oddzielną dzielnicą miasta Chmielnickie, to osoby przybyłe w czasie przesiedleń lat 30. bądź po wojnie, to nadal wsie są określane przez Polaków zamieszkałych na Podolu jako wsie mazurskie. 
Mazurzy, jak sami mówią o swoim pochodzeniu - „korzeń chłopski ale i polski”. Nie zgadzają się na nazywanie ich „Polonią" bądź "Polakami na Podolu”, traktując to jako uproszczenie. Ich polskość wiąże się z przywiązaniem do tradycyjnego wyznania - rzymskokatolickiego, dlatego też rola Kościoła katolickiego na tym terenie jest ogromna. Dodatkowym elementem, który wpływa na tożsamość grupy, jest pamięć o chłopskich korzeniach. Na ich samoidentyfikację wpływ ma pamięć o chłopskich korzeniach, polskość wyrażana przede wszystkim poprzez związek z Kościołem katolickim, język będący mieszanką polonizmów, rusycyzmów, ukrainizmów i słów gwarowych (zob. Krawczyk, 2007), a także pamięć o najtragiczniejszych wydarzeniach, które dotknęły grupę - represjach i głodzie lat 30. XX wieku.

\section{MAZURZY NA PODOLU - HISTORIA MIGRACJI}

Od XVI wieku rozpoczyna się obecność polskiej mniejszości na Podolu, przez cały wiek XVI i XVII z terenów etnicznie polskich migrowano na wschód, nie tylko z powodu zagrożeń, ale także coraz liczniejszych obciążeń poddańczych związanych z rozrastającymi się w XV i XVI wieku folwarkami. Najdawniejsze osadnictwo związane było z warstwami wyższymi, dopiero w XVIII wieku następuje masowa migracja chłopstwa, przede wszystkim z terenów Mazowsza (Voĭnarovs'ky̌̆, 2004, s. 155). Nowych osadników z zachodu pociągała wolność i swoboda. Ryzykowali, osiedlając się na terenach objętych ciągłymi napadami tatarskimi, jednak obejmowali oni takie obszary, jakie byli w stanie rolniczo obrobić (Iwanow, 2014, s. 33). Mazurzy zaludniali ogromne tereny Litwy, aż po Mariampol, Oszmianę, Polesie, Podole i Ruś Czerwoną, docierali także do terenów między Pilicą a Wisłą (Sembrzycki, 2002, s. 56). Rejon proskirowski był przez polską ludność najliczniej zamieszkiwany na przełomie XIX i XX wieku, stanowiła ona wtedy około $20 \%$ ogólnego zaludnienia (Wolski, 1994, s. 12). W okresie migracji z zachodu na Podole zaznaczały się dwie grupy polskiego osadnictwa, które miały specyficzne cechy społeczno-kulturowe: grupa chłopów, którą określa się mianem Mazurów, przesiedleńców-kolonizatorów z terenów etnicznie polskich i grupa szlachty, która pozostała po wojskowej służbie pilnowania i ochrony polskich granic przed najazdami Tatarów i Turków (Naulko, 1965, ss. 14-15). Mazurami nazywano tych, których definiowano jako najniższy stan społeczny kolonistów. W zasięg tej społeczności wchodziła zarówno zdeklasowana przez carat szlachta, tzw. szaraczkowa, jak i chłopi (Zowczak, 2004, s. 224). Na Podolu podział na wsie "mazurskie” - chłopskie i szlacheckie nadal jest zauważalny. Wsie szlacheckie materialnie dziś nie różnią się od wsi mazurskich, jednak dawne podziały stanowe do dziś istnieją w pamięci poszczególnych wsi. Szlachta przybyła na te tereny najwcześniej, by przetrwać jako grupa, zachowywała swój język i kulturę. Poczucie wspólnoty stanowej powodowało, że dawniej częściej wstępowano w związki małżeńskie ze szlachtą ukraińską niż z polską, chłopską, społecznością z wsi mazurskich (Zowczak, 2003, s. 34).

Dla tożsamości mazurskiej ogromne znaczenie miało i ma do dziś wyznanie rzymskokatolickie. Wsie mazurskie przetrwały dzięki ich jednolitości, ale także pewnego rodzaju zamknięciu się na obcych. Jak zaznaczali podczas badań rozmówcy, do II wojny światowej małżeństwa zawierano tylko w ramach wspólnoty wsi mazurskich. 80-letni mężczyzna wspomina:

Kiedyś tak było, jakoś do wojny, że żenili się chłopy z tymi z Maćkowiec, Szarawki, Zarzecza, Hreczan, to swoi byli, tacy sami byliśmy, bo Mazurzy. Teraz to cudze we wsi biorą [na żonę, 
na męża], nie brali z cudzych wsi dawniej. Po wojnie starzy mi mówili: „Jeśli żyjesz w Maćkowcach, to tutaj powinieneś żonę znaleźć". To jak brał sobie Ukrainkę albo prawosławną, to kiedyś ksiądz ślubu nie dawał. Jeśli ona chodzi na nauki, przejdzie [na wiarę rzymskokatolicką], to dadzą ślub. A teraz mieszane wszystko.

Przynależność do Kościoła rzymskokatolickiego miała ogromny wpływ na poczucie tożsamości u napływowej ludności polskiej, poprzez wyznanie szlachta ale i chłopi zachowywali świadomość swojej polskości (Wolski, 1994, s. 9).

\section{OKRES MIĘDZYWOJENNY}

W pamięci ludności polskiej Podola Wschodniego, należącego w okresie międzywojennym do ukraińskiej SRR, znaczące były wydarzenia lat 20. i 30. XX wieku. W sowieckiej polityce narodowościowej, nie tylko wobec mniejszości polskiej, można wyróżnić kilka etapów: lata 1921-1928 były czasem poszerzenia praw mniejszości narodowych, natomiast okres 1929-1935 był czasem ograniczenia praw mniejszości, by w latach 1936-1939 władza zlikwidowała swobody demokratyczne i zastosowała wobec mniejszości represje, ludobójstwo i prześladowania (Dzięgiel, 2003, s. 31).

Za czasów guberni podolskiej - czasów imperium rosyjskiego do lat 20. XX wieku Polacy nie byli ograniczani w prawach obywatelskich, mieli możliwość i przestrzeń rozwoju. Przez wieki ogromne znaczenie miał Kościół katolicki, który był ostoją polskości, konsolidował wspólnotę. Po rewolucji w 1918 roku sytuacja polityczna sprzyjała rozwojowi języka polskiego na tych terenach, aż do 1921 roku prowadzona była polityka ",korenizacji" - powrotu do korzeni, prowadzona przez władze UNR (1917-1921) oraz polityka władzy radzieckiej w stosunku do mniejszości narodowych i etnicznych (Rudnicki, 2000, s. 197). Jak pisze Artur Patek, położenie ludności polskiej w ZSRR było zawsze zależne od sytuacji politycznej w kraju, założeń ideologicznych oraz kursu polityki narodowej władz. Przykładem tego jest okres rozpoczynający się w 1921 roku i podjęta na X Zjeździe Rosyjskiej Komunistycznej Partii polityka autochtonizacji, korenizacji i unaradawiania, która polegała na przyznaniu narodom nierosyjskim szerokich praw językowych i kulturalno-oświatowych oraz stworzeniu narodowych instytucji lokalnej administracjii. Miało to spowodować, że uda się skutecznie zaszczepić nową socjalistyczną ideologię i wychować człowieka na miarę sowieckich czasów (Patek, 2011, s. 297). W latach 20. zrodziła się w ZSRR idea utworzenia polskich rejonów narodowościowych, które miały być „małą komunistyczną Polską" (Kuczyński, 2014, s. 80). Oprócz rejonu Marchlewskiego, z centrum w Dołbyszu i Dzierżyńskiego na Białorusi, autonomię polską chciano zorganizować także w okolicy Proskirowa na Ukrainie, z centrum we wsi Hreczany, obszar ten miał stać się kolejnym „polrejonem” (Patek, 2011, s. 298). Był to innowacyjny pomysł polegający nie na podzieleniu terytorium na jednostki administracyjne w cechach podatkowych, a na utworzeniu wysp samorządu narodowego, opartych na kryteriach grup etnicznych dominujących w danym regionie (Brown, 2013, s. 23). Ten eksperyment miał skutkować uformowaniem „radzieckiego Polaka, Niemca, Greka”, który miał być zarówno komunistą, jak i internacjonalistą, a jego przynależność narodowa miała wyrażać się tylko w odmiennym języku (Patek, 2011, s. 315). Eksperyment sowiecki, którego efektem miała być sowietyzacja Po-

Na terenie Ukraińskiej SRR znajdowały się także rejony narodowe: żydowskie, bułgarskie, niemieckie, greckie i mołdawskie. 
laków, nie powiódł się; bardzo silne było przywiązanie do Kościoła katolickiego oraz tradycyjnych form gospodarowania, co spowodowało niechęć do wstępowanie do kołchozów.

Ludność obszarów polskiej autonomii, mimo że traktowana w większości jako Polacy, była dość mocno zróżnicowana. Przykładowo na terenie Marchlewszczyzny 70\% mieszkańców definiowana była przez władze jako Polacy, jednak w rzeczywistości prawie połowa z nich posługiwała się językiem polskim, a jedynie część mówiła nim płynnie i na co dzień, a tylko niewielki odsetek znał polską kulturę i historię, w większości porozumiewano się za pomocą gwary, w której znaczące były ukrainizmy i rusycyzmy, natomiast materialnie ludność chłopska nie różniła się od okolicznych ukraińskich chłopów (Patek, 2011, s. 56). Elementem najbardziej znaczącym dla ludności Podola o polskich korzeniach była przynależności do Kościoła rzymskokatolickiego, która do dziś ma ogromne znaczenie. To kryterium było zabronione w definiowaniu nowych „radzieckich Polaków”, dlatego ustalenie minimalnego kryterium polskości stanowiło dla władzy w latach 20. problem. Bycie Polakiem w kontekście radzieckim i proletariackim było celem władzy i starano się je tak formułować, natomiast bycie Polakiem w znaczeniu obowiązującym przed rewolucją związane z Kościołem katolickim, szlachtą, burżuazją - stało się zbrodnią. Efekty tej problematyzacji kategorii „bycia Polakiem” w ukraińskiej SRR można było zauważyć w wytworzeniu się postaci wrogiej władzy: bogatego chłopa - kułaka ${ }^{5}$ (Stroński, 1996, s. 244).

Pozytywne nastawienie do grup etnicznych i narodowych zamieszkujących tereny radzieckiej Ukrainy szybko się zmieniło. Władze, widząc małą liczbę skolektywizowanych gospodarstw, zamieniły politykę narodowościową na metody represji i zaostrzenia reżimu politycznego (Stroński, 1996, ss. 244-245). Natomiast już w latach 1929-1931 rozpoczęto represje wobec Kościoła katolickiego, który cieszył się ogromnym autorytetem wśród ludności lokalnej, dlatego komuniści z nim właśnie rozpoczęli walkę o wpływy. W tym czasie aresztowano księży katolickich, nie odprawiano nabożeństw. W rejonie proskirowskim jednym z ważniejszych punktów, w których chrzczono dzieci i odprawiano msze, była kaplica w Hreczanach. Tak o walce z wiernymi chcącymi uczestniczyć we mszy opowiada 80-letni mężczyzna z Maćkowiec:

Babcia idzie [do kościoła], na święta, na Wielkanoc i sekretarz partii wychodził na drogę i babcia z dzieckiem idzie, to on nawraca, dziecko niech wraca do domu, a babcia niech idzie sobie dalej. A teraz komunisty same chodzą [do kościoła], udają, że nic tam nie było.

W czasie walki z religijnością w socjalizmie władza dławiła sprzeciw i karała za stawianie oporu. Nacisk kładziono na ateistyczne wychowanie dzieci i młodzieży. Jednym z przykładów walki z religijnością na tych terenach było wyznaczenie jako dnia wolnego od szkoły czwartku. W praktyce okazało się, że w niedziele i święta do szkoły uczęszczała mała liczba uczniów. Identyfikacja polskiej ludności Podola wschodniego z wyznaniem rzymskokatolickim w szczególności widoczna była po upadku ZSRR w żywotności polskiej ludności w odzyskiwaniu, remontach i budowie kościołów (Zowczak, 2003, s. 14). W Maćkowcach kościół postawiono dopiero po pierestrojce, wcześniej od lat 30. XX wieku do czasów niepodległej Ukrainy i budowy nowego kościoła chodzono na msze do kaplicy w Hreczanach. Jak wspominają rozmówcy, do lat 30. w miejscu lokalnego sklepu stała kaplica, w której spotykano się na modlitwy, jednak wraz z budową kołchozu i walką władz z religijnością obywateli, została ona wyburzona.

\footnotetext{
5 Innymi kategoriami, oprócz kułaka, którymi posługiwano się wobec ludności wrogiej sowieckiej władzy były: "rodziny uciekinierów za granicę", „element antyradziecki”, "kontrabandyści”, „aktyw kościelny”.
} 
Wobec zmiany nastawienia władz do mniejszości narodowych i etnicznych zamieszkałych na terenie Ukraińskiej SRR zamykano polskie kluby, biblioteki, szkoły, gazety, likwidowano administrację. Redakcje polskich gazet na Podolu, takich jak „Pograniczna Prawda”, zostały oskarżone o wprowadzenie na swoich łamach elementów nacjonalistycznych, propagowanie „obcych elementów” i podburzanie społeczeństwa (Misinkevych, 2004, s. 184). Rejony zamieszkiwane przez Polaków stały się w oczach władzy terenami potencjalnie wrogimi dla socjalizmu, dlatego rozpoczęły się represje: rozstrzelania, zesłania na Syberię i w północne rejony europejskiej części ZSRR, np. guberni archanielskiej (Kuczyński, 2014, s. 81). Władze zlikwidowały rejon Marchlewski i rozpoczęły wywózki ludności polskiej. Jeden z rozmówców tak opowiada o zesłaniu do Kazachstanu w roku 1936:

Represje rozpoczęły się pod koniec lat 20., naszą rodzinę wywieźli w 1936 roku do Kazachstanu, a wcześniej z Maćkowiec wywozili w 1927 roku na Sołówki, na północ, potem na Połtawę i ostatni transport do Kazachstanu. W Maćkowcach chyba połowę ludzi wywieźli miejscowych, to na ich miejsce przywieźli Ukraińców z Połtawy, nieliczni wrócili do wsi. Zabierali całymi rodzinami, majątek zabierał aktyw użytkowy, a materiał budowlany do kołchozu szedł.

W swojej książce Nikołaj Ivanov określa czystki etniczne z lat 30. XX wieku na ludności polskiej jako ludobójstwo, które potem dotknęło wszystkie grupy etniczne ZSRR. Wyjątkowy charakter represji antypolskich, ich skala w porównaniu z innymi narodami represjonowanymi, jak pisze autor, dają podstawę do określania Polaków „pierwszym narodem ukaranym" (Iwanow, 2014, s. 43) ${ }^{6}$. Represje dotknęły 25\% populacji polskiej na terenach Ukraińskiej SRR. Polska mniejszość w oczach władzy stała się społecznością oskarżaną o szpiegostwo na rzecz „pańskiej Polski” (Kuczyński, 2014, s. 82). Oczywiście istnieli także w tym czasie w oczach bolszewickiej władzy "dobrzy Polacy", czyli z perspektywy klasowej, biedni chtopi, robotnicy, komuniści.

W drugiej połowie lat 30. z obszarów nadgranicznych wysiedlano grupy narodowe na podstawie podejrzeń o nielojalność wobec państwa radzieckiego. Chłopi, którzy sprzeciwiali się kolektywizacji byli wrogami władz - kułakami. Powodem miał być dość duży opór społeczeństwa wobec kolektywizacji, polskie wsie, mimo propagandy, były najmniej skolektywizowane. Chłopi przywiązani do swojej ziemi, na której żyli od kilkuset lat, nieufnie spoglądali na nowy rodzaj gospodarki, w odpowiedzi na ich opór stosowano akcje „rozkułaczania", czyli wysiedleń zamożniejszych chłopów. W spisie powszechnym z 1926 roku zarejestrowano, że na terenie radzieckiej Ukrainy mieszkało 476000 Polaków. Szacuje się, że w latach 1929-1932 wywieziono około 10000 Polaków, w 1935 roku nastąpiła kolejna fala wywózek we wschodnie obwody Ukrainy, w której wysiedlono 30-40 000 ludzi, natomiast w 1936 roku nastąpiła największa deportacja, ok. 60000 osób do Kazachstanu (Dzięgiel, 2003, s. 32). 17 stycznia 1935 roku politbiuro podjęło decyzję o przesiedleniu do Kazachstanu chłopów z 5000 gospodarstw. Był to początek akcji najliczniejszych wysiedleń, w czasie których w latach 1935-1936 z Podola władza radziecka zesłała 11634 polskich rodzin (Misinkevych, 2004, s. 185). Czasy po zsyłkach w 1936 roku tak wspomina 85-letni mężczyzna z Maćkowiec:

Jak zabrali tych do Kazachstanu, to ich chaty zostały, zabrali ze sobą mało, to inni zamieszkiwali te chaty, a i przybyli na ich miejsce inni przesiedleńcy, [wcześniej] tu niedaleko żyli, koło Kijowa, takie ludzie czarnorobocze, biedne [rodziny] przesiedlali. 16 rodzin przesiedlonych było tutaj.

6 Do narodów ukaranych przez Stalina dołączyli: Koreańczycy, Ingermanlandczycy, Tatarzy Krymscy, Niemcy nadwołżańscy, Czeczeni, Ingusze, Bałkarzy, Kałmucy, Grzy, Bułgarzy, 
Pod nazwą „przesiedlenia” wywożono całe rodziny, zwłaszcza tych "niepewnych" w oczach władz, czyli zbyt bogatych, kultywujących wiarę mimo prześladowań religijnych. Byli oni wywożeni jako „wrogowie ludu”, „szkodniki polityczne” i "szpiedzy faszystowskiej Polski" (Kuczyński, 2014, s. 86). Na teren Kazachstanu także wywożono ludność wiejską, z prawobrzeżnej Ukrainy radzieckiej w celu rusyfikacji, ale także po to, by rozpowszechnić na tych terenach rolnictwo i uniezależnić się od sprowadzanego z zagranicy zboża (Hryciuk, 1996, ss. 220-221) ${ }^{7}$.

W latach 1935-1936 funkcjonariusze służb bezpieczeństwa wywieźli prawie połowę wszystkich zamieszkałych na tych terytoriach Polaków i Niemców. Jak pisze Kate Brown, były to pierwsze z sowieckich wywózek, w których za cel obrano grupy narodowościowe, a nie tylko klasy (Brown, 2013, s. 23). Jednak dla pozostałej na terenie Podola ludności najtragiczniejsze okazały się lata 1937-1938, w których władze komunistyczne zajęły się polityką likwidacji polskiej autonomii, wykorzystując politykę represji i ludobójstwa. „Wrogowie narodu" byli aresztowani, ginęli bez wieści, byli rozstrzeliwani. Powodem miała być działalność szpiegowska na rzecz Polski, związki z Polską czy też okazywanie swojej religijności (Dzięgiel, 2003, s. 33) ${ }^{8}$.

Wydarzeniem, do którego często powracali pamięcią rozmówcy, jest także Wielki Głód na Ukrainie w latach 1932-1933. Dziś jest on doświadczeniem granicznym dla wszystkich Ukraińców, należy do kanonu pamięci narodowej. Skolektywizowana gospodarka rolnicza nie mogła zaspokoić zapotrzebowania na produkty rolne, w wyniku czego wiele terenów ZSRR dotknął głód (Kuczyński, 2014, s. 83). W latach 1932-1933 na niektórych terytoriach śmiercią głodową zmarło 20-25\% ludności (Brown, 2013, s. 134)9. W przeciwieństwie do głodu z lat 20. władza radziecka nie poinformowała o klęsce opinii międzynarodowej, odrzuciła także wszelkie propozycje pomocy międzynarodowej, informacje dotyczące głodu uznawała za wymyst wrogów ZSRR (Serczyk, 2009, s. 311). Pamięć o Holodomorze łączy pamięć Mazurów Podola Wschodniego z pamięcią narodu ukraińskiego. Jeden z rozmówców w 1933 roku miał sześć lat:

W 1933 roku też głód pamiętam. To wtedy zabrali wszystkie pola nasze, to ludzie chodzili i szukali po kilka kłosków, to sądzili za to, niektórych pozsyłali. To niektórzy tu ginęli, nie wiadomo gdzie, no poszedł gdzieś i we wsi obok go rozstrzelali.

Holodomor jest jednym z wydarzeń, które odcisnęły swoje piętno na pamięci ludności wsi mazurskich, jest doświadczeniem, które może nosić miano granicznego. Tak o głodzie mówi 91-letni mężczyzna:

Lata kolektywizacji i głodu to były czasy okrutne. W 1933 roku ludzie puchli z głodu i umierali. Moją rodzinę uratował ojciec, bo zakopał woreczki kukurydzy w kilku miejscach. W komórce, na podwórzu, w nawozie, pod klepiskiem i pod jarzębiną, która rosła pod płotem. Chodziła komisja, taka trojka, i sprawdzała szpilcami metalowymi w ziemi i znajdywali. Znaleźli część [woreczków], a część nam uratowała życie.

7 Grzegorz Hryciuk pisze, że choć liczba przypadków śmierci dowodziłaby, iż deportacje do Kazachstanu miały charakter represyjny, nastawione były na fizyczną eliminację wrogów socjalizmu, to należy także dostrzec aspekt ekonomiczny tej decyzji.

8 Przykładem jest wieś Hreczany, dziś dzielnica miasta Chmielnickie, w której po zwrocie sowieckiej polityki względem mniejszości, w drugiej połowie lat 30. w czasie represji zabrano ze wsi około 90\% mężczyzn.

9 Prawdopodobnie z powodu słabej kolektywizacji wsi w rejonach szepietowskim i płoskirowskim głód w latach 1932-1933 nie spowodował tak wielkich strat w ludności lokalnej jak np. na terenie Poltawszczyzny, gdzie ginęły całe wsie. W rejonach płosikorowskim i szepetowskim, tam gdzie w 1930 roku zaczęły się rozruchy przeciw kolektywizacji, śmiertelność z powodu głodu nie wzrosła tak znacznie jak na terenie Ukrainy Środkowej. 
Radziecki reżim zaprzeczał istnieniu głodu, do czasów niepodległej Ukrainy, to wydarzenie było białą plamą pamięci. W czasie tragedii nikt nie prowadził ewidencji ofiar, dlatego trudno podać ich liczbę. Według obliczeń ukraińskich historyków i demografów liczba ofiar sięga od 4 do 5 milionów (Hrycak, 2000, s. 184). Pamięć o głodzie i kolektywizacji, a także czas późniejszych zsyłek są fragmentami najnowszej historii, o której pamiętają nawet najmłodsze pokolenia polskiej ludności Podola. Jak pisze Anna Wylęgała, pamięć o Holodomorze na terenie sowieckiej Ukrainy jest tragedią związaną w pamięci rodzinnej z bezpośrednim doświadczeniem, które dla społeczności mającej rodzinne korzenie na wsi jest wydarzeniem odległym o dwa-trzy pokolenia, dlatego także możliwy jest przekaz wspomnień przez świadków kolejnym pokoleniom w ramach pamięci komunikatywnej (Wylęgała, 2015, ss. 102-103). Jarosław Hrycak natomiast zaznacza, że głód na radzieckiej Ukrainie był nie tylko powodem start w ludziach i ciosem moralnym, ale też spowodował szkody - prawie całkowicie zniszczona została ukraińska wieś i jej bogata tradycja ludowa, jej miejsce zajęła wieś kołchozowa (Hrycak, 2000, s. 185).

\section{MAZURZY Z MAĆKOWIEC - PAMIECĆ O KORZENIACH POLSKICH I CHLOPSKICH}

W Słowniku geograficznym Królestwa Polskiego czytamy o Szaraweczce, Zarzeczu, Hreczanach i Maćkowcach jakoby ich mieszkańcy: "Jak sami dowodzą wyszli z Kujaw, i osiedlili się tu w ostatnich latach przeszłego wieku. Mazurzy odosabniają się zupełnie od innych warstw ludności okolicznej, łącząc się ściślej pomiędzy sobą" (Sulimierski, Chlebowski, \& Walewski, 1884, s. 888). Pamięć o czasie i charakterze migracji Mazurów na tereny Podola nie była zaznaczana w opowieściach rozmówców z Maćkowiec. Określano początki wspólnoty wsi, zaznaczając jej polskie, a zarazem chłopskie korzenie, co według rozmówców różniło mieszkańców mazurskich wsi od wsi "szlacheckich" na tych terenach. Wśród mieszkańców wioski niektórzy mówią o pochodzeniu swoich przodków od Mazurów, inni natomiast zaznaczają tylko pochodzenie pierwszych osadników z terenów dzisiejszej Polski, jak opowiada 91-letnia kobieta:

My Mazury tutaj, tak jak w Polsce tam w Katowicach inni [etnicznie], niż reszta Polaków, w górach inni, w Rzeszowie [inni], no my niby Polacy ale tak samo jak tamci z gór trochę inni od reszty Polaków ale nie czyści Polacy.

Znamienny wydawał się w czasie rozmów brak wiedzy odnośnie do czasu przybycia Mazurów na te ziemie. Zaznaczano przede wszystkim "dawność" tej migracji. Ważnym elementem opowieści o przybyciu Mazurów na tereny Podola była kwestia migracji z terenów etnicznie polskich. Jeden z rozmówców (78lat) tak opisuje migrację Mazurów na wschód:

To było dawno temu, po tym jak Turcy tutaj zrównali z ziemią wsie. Wielki Pan jakiś hrabia tu-

taj Mazurów zaprosił, by z Polski przyjechali, osiedlili się bo to silni ludzie byli. Dawno, dawno to było, kilkaset lat temu, jak tu przyjechali, jak Polska tu była.

W rozmowach wielokrotnie zaznaczano, że bycie Mazurem nie jest równoznaczne z byciem Polakiem. Niepewność jeśli chodzi o polskość Mazurów ujawnia się w ich określeniach siebie: "Mazury to takie ni to Ukraińcy, ni Polacy" (mężczyzna w wieku 70 lat), "Mazury to ludzie stąd, co tu żyją od wieków" (kobieta, 24 lata), "My tu to polscy chłopi, swój język mamy ni to polski, ni rosyjski, ale na pewno nie ukraiński" (kobieta, 40 lat). 
Mieszkańcy wsi określanych jako mazurskie, według Ewy Dzięgiel odróżniają się w samoidentyfikacji od "Polaków” i od "Lachów”, czyli ludności pochodzenia szlacheckiego (za: Krawczyk, 2007, s. 13). O tym podziale wspominali także mieszkańcy Maćkowiec:

Są tu obok takie wsie, że one nie mazurskie ale polskie są, oni nie gadają tak jak my tutaj, po naszemu, mazursku ale teraz po ukraińsku już, a wcześniej Kudryńce, Hudaczkowce tam Polaki ale teraz po ukraińsku gadają, wcześniej po polsku gadali. Między sobą oni też już po ukraińsku (mężczyzna 92 lata).

Ogromne znaczenie dla tożsamości Mazurów ma właśnie kwestia stanowa, pamięć o ich chłopskim pochodzeniu ma decydujący wpływ na samoidentyfikację grupy. Oprócz tego, że w ramach wsi są "swoi”, zamieszkują te tereny od kilkuset lat i zaznaczają to w rozmowach, to określają się jako odmienni zarówno od Polaków na tych terenach, jak i Ukraińców. Spoglądając na dawny stereotyp „Polak - katolik - szlachcic”, ponieważ Mazurzy nie są szlachcicami, dlatego także sami o swojej polskości mówią tak jakby była ona czymś wybrakowanym. Kilkakrotnie, gdy mówiłam o wsi jako o miejscu zamieszkania Polaków, byłam poprawiana: „Jakie tam Polaki, Mazury po prostu” (kobieta, 45 lat). Dzisiejsza polskość Mazurów traktowana jest raczej jako możliwość otrzymania Karty Polaka i wyjazdu zarobkowego na teren Unii Europejskiej, a także przez pryzmat przynależności do Kościoła katolickiego.

Jak podaje Aleksandra Krawczyk, według carskich statystyk w 1905 roku wieś zamieszkiwało 1161 rzymskich katolików i 7 prawosławnych, dziś natomiast wieś liczy okoto 2500 mieszkańców i nadal w większej części jest polska (Krawczyk, 2007, s. 13). Ta językoznawczyni, która we wsi prowadziła badania gwary mazurskiej, zaznacza, że na tle innych wsi polskich Maćkowce wyróżniają się pod względem znajomości języka polskiego. Oprócz tego, że po polsku mówi najstarsze pokolenie, także średnie i młodsze mówi bądź rozumie gwarę: „Mieszkańcy swobodnie rozmawiają gwarą na niemal wszystkie tematy" (Krawczyk, 2007, s. 14). Nawet przyjezdni Ukraińcy, którzy mają małżonka Mazura, mówią gwarą. W czasie badań spotkałam Hucułkę, która była żoną mężczyzny z Maćkowiec i wraz z nim zamieszkała we wsi. Zwróciła ona uwage na przymus rozmawiania gwarą w ramach wspólnoty:

Ja na początku jak obca się czułam, bo tu już prawie w środkowej Ukrainie nikt po ukraińsku nie chciał mówić. Odpowiedzą, ale potraktują jako przyjezdnego, tak przypadkowo. A jak chciałam być jak swoja, to w kościele zaczęłam pomagać i gwarą mówię, już nawet nie wiem kiedy po ukraińsku, a kiedy po mazursku.

Mimo że gwara nie ma wysokiego prestiżu, jej pozycja, jak pisze Krawczyk, jest silna i stabilna. Język polski utrzymał się w okolicach dawnego Proskurowa zapewne z powodu liczebności Mazurów-Polaków i ich zwartości (Krawczyk, 2007, s. 18). Język ukraiński dziś ma status języka państwowego, dzieci uczą się go w przedszkolach i szkołach, jednak we wsi starsze pokolenie zwraca uwage na używanie języka polskiego w domu. W czasie moich odwiedzin u jednej z rodzin, najstarszy jej członek, senior rodu (85 lat) chwalit się, że żaden z jego zięciów czy synowych "nie-Mazurów” nie mówi w domu po ukraińsku czy rosyjsku: "Mimo że to Ukraińcy, to uczą się mówić jak my, i to jakoś im w końcu w krew wchodzi".

Małżeństwa mieszane dla tej społeczności są zjawiskiem dość nowym, ponieważ powszechne zaczęły być dopiero po II wojnie światowej, wcześniej wielu badaczy zaznaczało zamknięcie grupy i niechęć wobec osób z zewnątrz (Krawczyk, 2007, s. 16). Po wojnie drobna szlachta, jak i Mazurzy zaczęli pracować w jednym kołchozie, dlatego 
też różnice stanowe przestały mieć takie znaczenie jak kiedyś (Straczuk, 2006, s. 65). Jak wspomina jeden z najstarszych rozmówców (94 lata): "Jak byłem młody matka by nie pozwoliła żebym za Ukrainkę wyszedł, za swoich trzeba było, nikt nawet nie zmieniał tego, a jak ktoś obcą wziął [za żonę] to wyjeżdżał zazwyczaj". Rozmówcy zwracali uwagę, że poczucie odrębności od "Lachów" - drobnej szlachty objawiało się również poprzez zwyczaj zawierania małżeństw w obrębie jednego stanu. Nazwa Mazurów nie odnosi się do miejsca pochodzenia polskich chłopów, ale jest określeniem różniącym tę grupę od Lachów-szlachty polskiej (Dzięgiel, 2003, ss. 40-41). Mazur nie jest nazwą etnonimiczną, ale jest związana ze sposobem prostego chłopskiego mówienia, zwanego mazurzeniem, które przez językoznawców jest określenie jako charakteryzujące się cechami gwar etnicznie polskich, lecz niewłaściwe dla języka ogólnopolskiego miejscowej inteligencji ani dla południowo-wschodniego dialektu kresowego, którym posługiwała się szlachta polska (Dzięgiel, 2003, s. 42).

Jedną z ważniejszych instytucji we wsi jest kościół pw. Narodzenia Najświętszej Maryi Panny. Nie tylko zrzesza on wspólnotę, ale także jest miejscem, w którym organizowane są zabawy, warsztaty dla dzieci czy nauka gry na gitarze. Kościołem od kilkunastu lat opiekują się zakonnicy-franciszkanie. Jak wspominają rozmówcy, od tego czasu kościół stał się „centralnym punktem wsi". Dla lokalnej ludności jest miejscem nie tylko modlitwy ale buduje wspólnotę i „wprowadza życie” do wsi: „Jak nie było kościoła, to znaczy tych franciszków jak nie było, to tu nic się nie działo. A oni i dzieci angażują i kościół pełny co niedzielę. Nie tylko modlitwa ale i zabawa, coś tam organizują, spotkamy się wszyscy (kobieta 40 lat)".

Kościół rzymskokatolicki dla ludności polskiej na terenie prawobrzeżnej Ukrainy jest nie tylko wyznacznikiem tożsamości grupy, ale także świadczy o walce o własną tożsamość W czasach represji. W czasie ukraińskiej SRR ludność odsunięta od instytucji Kościoła, niemająca przywódcy duchowego, sama podtrzymywała tradycje religijne - modlono się w domach, zbierano się potajemnie w kołach różańcowych, przy zmarłych, choć władza usilnie walczyła i chciała wytępić religijność, traktując ją jako element wrogi systemowi. Ochrzczenie dziecka, nawet w czasach represji i walki z religijnością, według rozmówców było koniecznością:

Nawet komunisty lokalne, oni niby nic nie wiedzą, pracują, tu jakaś babusia wzięła ich dzieci do Hreczan i ochrzciła. Jeśli dowiedzieli się, że komunista chrzcił dziecko, to z roboty go wyrzucali. Nawet takie akcje były, że babki, dziadki chrzcity te dzieci, zanosity do Greczan, to z władzy ci stawali na drodze głównej i nawracali takich starych z dziećmi małymi na rękach (mężczyzna 90 lat).

Przez pewien okres w ogóle nie było możliwości udzielenia sakramentów świętych przez księdza. Dopiero w czasie wojny wraz z okupacją niemiecką, pojawiła się możliwość praktykowania pracy duszpasterskiej przez księży, wtedy także zaczęto masowo chrzcić dzieci oraz brać śluby. Jeden z rozmówców wspomina (mężczyzna lat 60):

Do wojny to kościół nowy, ładny był w mieście, taki polski kościół, to rozbąbili go sowiety, a po wojnie to w Hreczanach się modlili ale tak kościoła nie było [we wsi], tylko taka kaplica ale wtedy to dużo było i tak. Po wojnie to ten kościół w mieście tankami rozbili.

Po wojnie w Hreczanach otwarto kaplicę cmentarną, która spełniała rolę kościoła. Władza starała się przeszkodzić w życiu religijnym, na przykład wyznaczając prace w kołchozie czy zabraniając uczniom chodzenia do kościoła. W latach 90. mieszkańcy wsi Maćkowce postanowili odbudować kaplice cmentarną, zburzoną w latach terroru, i wznieśli mały 
kościółek własnymi rękami i z własnych środków (Krawczyk, 2007, s. 17). Elementem walki ludności rzymskokatolickiej z ateizacją terenów Ukrainy Radzieckiej był żywy różaniec, który jest uważany za jeden z wyznaczników katolicyzmu, zarazem dla Mazurów jest znakiem tożsamości i pamięci o czasach religijnych represji. Do tego czasu „Róże” obecne są w każdym kościele katolickim na Ukrainie. Odmawianie różańca było spoiwem wiążącym człowieka zarówno ze wspólnotą religijną jak i społeczną. Za czasów sowieckich był to wręcz jedyny przejaw autentycznej i niezależnej od władzy bolszewickiej wspólnoty religijnej, a przede wszystkim polskiej (Zowczak, 2004, ss. 241-242). Dla NKWD i KGB różaniec był działalnością tajną, podejrzaną, niebezpieczną dla idei socjalistycznych, dlatego właśnie należało go tępić. Represje, zniszczenie dawnych zabytków polskich, eliminacja części polskiej ludności tych terenów w opowieściach rozmówców potwierdzają wartość dawnej zakazanej, niebezpiecznej dla władzy polskości i religii. W przypadku podolskich Polaków to właśnie ich przynależność do Kościoła katolickiego i gwara jest elementem polskiego charakteru ich tożsamości.

W kościele w Maćkowcach msza święta odprawiana jest przez franciszkanów w języku polskim, natomiast kazanie głoszą oni w języku ukraińskim. Pieśni śpiewane przez starsze kobiety przed mszą były pieśniami polskimi, jednak w czasie mszy śpiewano zarówno ukraińskie, jak i polskie pieśni, a w śpiewniku nad zdaniami polskimi znajdował się fonetyczny zapis w cyrylicy w celu, jak mówili rozmówcy: „ułatwienia dzieciom i młodym uczestnictwa w mszy". Ta różnica pokoleń w znajomości języka polskiego nie dziwi najstarsze pokolenie miało do niego dostęp, chociażby poprzez kontakt ze swoimi rodzicami, którzy żyli w okresie działalności polskiego samorządu i szkół w latach 20.-30. XX wieku. Młodsze pokolenia, te urodzone w latach 1950-1960, znajomość języka polskiego nabyły raczej w kontaktach z Polską (Zowczak, 2003, s. 51).

Msze święte w kościele w Maćkowcach prowadzone są po polsku i ukraińsku, jednak to język pacierza i modlitwy prowadzonej w domu dla rozmówców świadczył o polskich korzeniach grupy. Najstarsi rozmówcy wspominali, że nie wyobrażają sobie modlenia się w języku ukraińskim. Ta przynależność języka polskiego do sfery religijnej - modlitw i kantyczek przekazywanych z pokolenia na pokolenie jest pewnym rodzajem dziedzictwa wspólnoty. Jak pisze Zowczak, modlitwy to nie tylko słowa, ale także znak krzyża, gesty, które stają się językiem ciała:

Nauczony przez matkę czy babkę pacierz to słowa, gesty, skojarzenia, w które człowiek wrasta od najwcześniejszego dzieciństwa, tak, że trudno je wymazać z pamięci; można je najwyżej wyprzeć ze świadomości, a i wówczas powrócą we śnie. Należą więc do rudymentów kultury (Zowczak, 2004, s. 236).

Proces nauki pacierza czy sama forma modlitwy są formą pamięci ucieleśnionej, o której Paul Connerton pisze, że jest rodzajem pamięci nawykowej, w której zdolności do wykonywania pewnych ruchów są możliwe bez odnoszenia się wspomnień do nich (Connerton, 2012, ss. 145-146). Przekazywane z pokolenia na pokolenia nawyki takie jak modlitwa opierają się na wiedzy, nie tylko o własnych korzeniach czy dziedzictwie, ale i pamiętaniu zawartym w ciele. Modlitwy w języku polskim stanowią spoiwo tożsamości Mazurów - coś, co odróżnia ich od otoczenia, co wpływa na ich „poczucie siebie w grupie", co powoduje, że nawet w okresie represji w czasach sowieckich zachowali swoją tożsamość, ponieważ, jak mówią, bycie katolikiem jest najważniejszym elementem bycia Mazurem, scala pamięć o korzeniach grupy i odróżnia ją od innych.

Ogromnie ważnym miejscem z perspektywy pamięci wspólnoty wsi jest okoliczny cmentarz. Określa on wioskową przynależność wyznaniową, co w kontekście pogranicza 
ma ogromny wpływ (Straczuk, 2006, s. 58), jest też miejscem o ambiwalentnym znaczeniu. Mnogość czynności wiążących się z cmentarzem, związanych z nim myśli, wyobrażeń, wspomnień powoduje, że jest on nazywany przez Foucaulta heterotropią, a więc na cmentarzu przeciwstawia się kilka wymiarów czasowych i kilka warstw znaczeniowych w jednej przestrzeni (za: Straczuk, 2006, s. 67). Cmentarz jest także odbiciem wewnętrznych podziałów wsi, daje nam możliwość odczytania systemu grup i rodzin. Jeszcze do lat 80.-90. XX wieku spotykanie się na mogiłach przodków było dla podolskich katolików koniecznością z powodu walki z religijnością lokalnej ludności. Powojenna akcja niszczenia świątyń była dopiero zapowiedzią największych represji, których apogeum przypadło na rok 1938, wówczas modlitwa była możliwa tylko w domu (Zowczak, 2003, s. 46). Cmentarz był miejscem praktyk religijnych ale także miejscem pamięci będącym swoistym jej nośnikiem. W szczególności mogiły na pograniczach ukazują kształt i treść pamięci społeczności lokalnej, będąc tekstem kultury, odczytane dostarczają dodatkowych informacji na temat samookreślania się grupy (Straczuk, 2006, s. 58).

Mogiły zmarłych ze wspólnoty, które przychodzi się porządkować i dekorować na wszystkie święta, są wyrazem pamięci prywatnej i mało widzialnej, dostępnej tylko dla wtajemniczonych. Grób stanowi substytut przestrzeni zmaterializowanej wokół zmarłego za życia, cmentarz jest takim substytutem wokół ogółu zmarłych, rozumianych jak grupa etniczna, narodowa, wyznaniowa, „Czasem po prostu inna” (Kolbuszewski, 1994, s. 30), jak w przypadku wydzielania przestrzeni dla osób zmarłych „nie w porę”, czyli śmiercią nagłą. W Maćkowcach na cmentarzu miejsce dla samobójców znajduje się na tyłach cmentarza, w oddaleniu od reszty nagrobków. Interesujące, że groby te, nawet nowe, w większości nie mają podpisów, a tylko krzyże. Może być to pozostałością po dawnym traktowaniu osób zmarłych śmiercią tragiczną, które nie miały czasu na odpowiednie „przygotowanie się" do śmierci. Jeszcze w czasach powojennych pogrzeby samobójców pozbawione były wymiaru sakralnego, zarówno przez odmowę pogrzebania w poświęconej ziemi, jak i zakaz wspominania imienia zmarłego podczas pogrzebu. Tym sposobem zmarli "śmiercią nie w porę" skazani byli na wykreślenie z miejscowej wspólnoty zmarłych, a więc skazani na zapomnienie (Straczuk, 2006, s. 119).

Ważnym dla wspólnoty lokalnej miejscem jest centrum cmentarza. Przykładem tego jest wydzielanie przestrzeni cmentarza dla zasłużonych i ważnych dla pamięci wspólnoty zmarłych, a także umiejscawianie pomników osób ważnych w centralnym punkcie cmentarza. Takim miejscem we wsi Maćkowce jest znajdujący się w centrum pomnik ofiar z okresu represji i wojny lat 30.-50. XX wieku. Wypisane nazwiska mają upamiętniać osoby, które zginęły dla wspólnoty. Napis na głównej ścianie pomnika głosi:

Ofiarom:

Wielkiej wojny 1941-1945

Represjonowanym 1937-1938

Wielkiego Głodu 1933-1934

Poszczególne tablice z nazwiskami i inicjałami imion poświęcone są konkretnym grupom ofiar: zaginionym na frontach wojennych (1941-1945), ofiarom rozerwanym na minach w wiosce w latach 1944-1950; osobom, które zaginęły bez wieści w latach wojennych; zaginionym w czasie Wielkiego Głodu, represjonowanym i zesłanym w latach 1937-1938. Ten wybudowany z pieniędzy wspólnoty pomnik ofiar tego czasu jest pewnym zaprzeczeniem pomnika "Wielkiej Wojny Ojczyźnianej”, ufundowanego przez władzę, który stoi w centrum wsi, a napis na nim głosi: 
Wieczna pamięć bohaterom,

którzy zginęli za wolność i niezależność naszej ojcowizny 1941-1945¹0.

Śmierć wiąże się nieodłącznie z kształtowaniem pamięci - nie tylko o poszczególnych osobach, ale także o losach całej społeczności, ta pamięci jest ważnym elementem tożsamości wspólnoty. Najstarsza część cmentarza zawiera metalowe krzyże, na których nie ma tabliczek. Na moje pytanie, dlaczego groby te są bezimienne, młoda kobieta odpowiedziała:

Tam leżą nasi prapradziadkowie. Kto pamięta, to chodzi [na groby] ale ja już nie wiem gdzie te groby nasze są, ja tylko pradziadków kojarzę, ale oni już w tej nowszej części leżą. A tak mniej więcej to pamiętam gdzie te najstarsze rodzinne groby to tam znicz postawię w tej okolicy (kobieta, 31 lat).

Jak pisze Justyna Straczuk, owo "gdzieś tam” jest pewnym punktem pamięci, charakteryzuje chłopskie korzenie wsi. Taka pamięć szybko traciła swój jednostkowy charakter. W kulturach tradycyjnych przedkładano życie zbiorowe nad indywidualnym, ważna była wspólnota, kult przodków charakteryzował się pamięcią i szacunkiem wobec ogólnych, anonimowych przodków związanych raczej z pamięcią wspólnoty niż pamięcią konkretnej rodziny (Straczuk, 2006, s. 69). Oczywiście dziś na terenie cmentarza w Maćkowcach widzimy nagrobki kamienne, z napisem zawierającym dane zmarłego. Jednak podejście do starszych grobów ukazuje nam specyfikę znaczenia przestrzeni cmentarza dla zbiorowej pamięci i identyfikacji grupy. Cała przestrzeń najstarszych grobów mimo, że zadbana charakteryzuje się brakiem podpisów na nagrobkach. Dawniej na cmentarzach wspólnot chłopskich ważna była sama przestrzeń cmentarza, a nie poszczególne nagrobki, dlatego także cmentarz "rozrastał się w dół”. Jak pisze Justyna Straczuk,

Kolejne warstwy tej pamięci to leżący jedni na drugich zmarli, którzy zlewają się w uogólnioną społeczności anonimowych przodków, jeden zbiorowy grób "dziadów". Owa pamięć narasta niejako w głąb, nasycając cmentarną ziemie coraz gęstszą (w sensie dosłownym i przenośnym) treścią (Straczuk, 2006, s. 69).

Ziemia cmentarza sama w sobie jest nośnikiem pamięci o ambiwalentnym znaczeniu. Do dziś dnia, jak mówili rozmówcy, obowiązuje zakaz przynoszenia czegokolwiek z cmentarza do domu, cmentarz bowiem ma własną aurę związaną ze śmiercią i jest miejscem mediacji ze światem zmarłych. Jak wspomniała jedna z młodszych rozmówczyń (25 lat):

Chodzimy z małym (półroczny synek, który jest jeszcze nieochrzczony) na spacery ale takie krótkie, blisko domu, bo jeszcze nieochrzczony jest, czekamy aż jego tata wróci z frontu.

A dlaczego dalej nie możecie pójść?

No niebezpiecznie jak nieochrzczony [synek], na cmentarz na przykład nie można, bo ochrony dziecko nie ma przed tym co może być w ziemi.

Ziemia cmentarna kiedyś była esencją cmentarza, to w niej spoczywały kości, znak zaczepienia pamięci żyjących członków wspólnoty. Jak wskazuje powyższy cytat ziemia pod cmentarzem jest medium, które łączy świat żywych ze zmarłymi. Szczątki przodków wspólnoty żyjącej na tym samym terenie przez setki lat, jak w przypadku Mazurów z Maćkowiec, są znakiem trwania w czasie całej społeczności, elementem zakorzenienia.

10 Interesujące, że w niewielkiej odległości od pomnika ofiar Wielkiej Wojny Ojczyźnianej wspólnota wsi ufundowała pomnik Matki Boskiej, stojący na kolumnie. Jak opowiadali rozmówcy, w miejscu pomnika Matki Boskiej stał dawniej pomnik Lenina, który został obalony przez ludność wsi na początku niepodległej Ukrainy. 
W porównaniu do pamięci szlacheckiej, pamięć chłopska jest krótsza i mniej „dopracowana". Najstarsze pokolenie, to urodzone przed wojną albo w jej czasie, pamięta tylko imiona dziadków, tych których znało za życia. Rodziny z korzeniami szlacheckimi gromadzą pamiątki i wspomnienia w sposób intencjonalny, pamięć o korzeniach jest istotnym elementem tożsamości, dlatego też kultywuje się ją, zabiega o jej trwałość. W chłopskich rodzinach także istnieje pamięć o przodkach, jednak jest to pamięć nie o indywidualnych osobach, ale o pewnych wzorcach osobowych (Straczuk, 2006, s. 67). Pamięć chłopska obejmuje swym zasięgiem trzy pokolenia, rzadko kiedy wychodzi poza nie (Straczuk, 2006, s. 65).

Interesującym wątkiem w kontekście pamięci rodzinnej wśród wspólnoty Maćkowiec jest kwestia używania w wiosce przydomków zamiast nazwisk. Rozmówca w wieku okoto 70 lat zaznaczył: „To po ulicznemu ludzie lepiej znają niż po familii. To tak to jest, że tato był tak nazywany, dziadek, ja i mojego syna, wnuka też [tak nazywają], tak idzie". Ponieważ nazwiska i imiona na wsi powtarzają się, w powszechnym użyciu są przydomki, przykładem tego są moje poszukiwanie starszego mężczyzny o nazwisku Bondar. Okazało się, że mężczyzn o tym nazwisku i imieniu jak powiedziała pewna kobieta, „jest we wsi chyba z trzech". Dlatego we wsi używane są przydomki takie jak np. Muzyczko, Ptaszuk, Jamróz, które nawiązują do specyfiki męskiej części korzeni rodzinnych. Przykładem może być przydomek Ptaszuk, który rozmówca w wieku 80 lat odziedziczył po swoim dziadku i przekazuje dalej, od przydomka tworzone są określenia „Ptaszukowa córka, żona”, „u Ptaszuków” - przydomek „rezonuje” na całą rodzinę. Jak mówi rozmówca: „U nas tak było, że mój dziadek, mój ojciec mieli gołębie, ja też mam i stąd te Ptaszuki". Natomiast mężczyzna mający przydomek „Muzyczka”, którego dziadek miał być ludowym muzykantem, tak mówił o kwestii przezwisk:

To ja sam nie wiedziat, tak nazywali... Muzyczka to po ulicznemu, mój dziadek grał i tak nazywali [śmiech - dop. M. J.]. Ja nie pamiętał na czym dziadek grat, to ludzie wiedzieli, i tak poszło, ja nie wiedziałem skąd to ale tak zwali od małego.

Rozmówca "Muzyczka" scharakteryzował swoją rodzinę słowami: "Mówią na wsi: To od Muzyczka, wnuk od Muzyczka, mówią, to weseli ludzie". Jednolitość nazwisk we wsi jest dowodem jej kilkusetletniej zasady endogamii, powtarzające się nazwiska o „chłopskim korzeniu" takie jak: Bondar, Bigos, Sowa, Karol, Kozak, Kłacz, powodują, że we wspólnocie nadal używane są przydomki będące, jak wspominali rozmówcy, "nazwami po ulicznemu”. Mieszkańcy okolic Chmielnicka określając się jako "Mazurzy” zaznaczali specyfikę swojej tożsamości opierającej się nie tylko na chłopskich korzeniach, które są dla wspólnoty dziedzictwem, ale też na przywiązaniu do polskości wyrażanej w przynależności do Kościoła katolickiego i posługiwaniu się specyficzną gwarą, a także pamięci o represjach, które dotknęły grupę w czasach stalinowskich.

\section{ZAKOŃCZENIE}

Największy wpływ na tożsamość Mazurów Podola Wschodniego mają wydarzenia, które dotknęły grupę $w$ XX wieku, związane przede wszystkim z polityką narodowościową władz w latach 20., kolektywizacją wsi i zmianą nastawienia władz wobec mniejszości narodowych i etnicznych, wiążącą się z likwidacją narodowych autonomii na terenie radzieckiej Ukrainy i represjami lat 30 . Dziś ludność wsi mazurskich pamięta o swoich 
chłopskich i polskich korzeniach, jednak zaznacza specyfikę swojej tożsamości określając siebie mianem Mazurów, a nie zgadzając się na nazywanie ich Polakami, czy Polonią na Podolu. Podczas rozmów zaznaczano różnicę w tożsamości wspólnot polskich-szlacheckich od chłopskich-mazurskich. Bliskość miasta spowodowała, że młode pokolenia pozostają w rodzinnych wioskach i przejmują dziedzictwo wspólnoty lokalnej. Wiele osób ze wsi migruje zarobkowo za granicę, jednak powraca do swoich wsi, buduje tu domy, wychowuje dzieci. Jednym z ważniejszych elementów tożsamości społeczności lokalnej jest wyznanie rzymskokatolickie. Kościół katolicki jest dla ludności lokalnej jednym z najważniejszych centrów we wsi, nie tylko zrzesza wspólnotę, ale także jest dowodem jej długiego trwania na tych terenach i znakiem przetrwania wspólnoty religijnej przez dziesięciolecia represji religijnych.

\section{BIBLIOGRAFIA}

Assmann, A. (2013). Między historią a pamięcią: Antologia. Warszawa: Wydawnictwa Uniwersytetu Warszawskiego.

Brown, K. (2013). Kresy: Biografia krainy, której nie ma: Jak zniszczono wielokulturowe pogranicze (A. Czwojdrak, Tłum.). Kraków: Wydawnictwo Uniwersytetu Jagiellońskiego.

Connerton, P. (2012). Jak społeczeństwa pamiętają (M. Napiórkowski, Tłum.). Warszawa: Wydawnictwa Uniwersytetu Warszawskiego.

Dzięgiel, E. (2003). Polszczyzna na Ukrainie: Sytuacja jezzykowa w wybranych wsiach chłopskich i szlacheckie. Warszawa: Wydawnictwo Naukowe Semper.

Hrycak, J. (2000). Historia Ukrainy 1772-1999: Narodziny nowoczesnego narodu(K. Kotyńska, Tłum.). Lublin: Wydawnictwo Instytutu Europy Środkowo-Wschodniej.

Hryciuk, G. (1996). Patria in exsilio?: Masowe deportacje radzieckie do Kazachstanu w latach 30.-50. XX wieku. W S. Ciesielski \& A. Kuczyński (Red.), Polacy w Kazachstanie: Historia i współczesność (ss. 211-238). Wrocław: Wydawnictwo Uniwersytetu Wroctawskiego.

Iwanow, N. (2014). Zapomniane ludobójstwo: Polacy w państwie Stalina „Operacja Polska" 1937-1938. Kraków: Wydawnictwo Znak.

Kolberg, O. (1994). Dzieła wszystkie: T. 47. Podole. Wrocław: Wydawnictwo Polskie Towarzystwo Ludoznawcze.

Kolbuszewski, J. (1994). Pejzaż semiotyczny pogranicznych cmentarzy. W T. Smoliński (Red.), Pogranicze jako problem kultury: Materiaty Konferencji Naukowej Opole 13-14.12. 1993 r. (ss. 77-86). Opole: Wydawnictwo Uniwersytetu Opolskiego.

Krawczyk, A. (2007). Zapożyczenia leksykalne w sytuacji wielojęzyczności: Ukrainizmy i rusycyzmy w gwarze Maćkowiec na Podolu. Warszawa: Wydawnictwo DiG.

Kuczyński, A. (2014). Polacy w Kazachstanie: Zestania, dziedzictwo, nadzieje, powroty. Krzeszowice: Wydawnictwo Kubajak.

Malinowski, B. (1958). Szkice z teorii kultury. Warszawa: Wydawnictwo Książka i Wiedza.

Misinkevych, L. (2004). Represyvna polityka shcho do Poliakivv Podillia v 30-n rr. XX stolittia. W H. Stroński (Red.), Pamiętnik Kijowski: T. 7. Polacy na Podolu: (ss. 181-189). Kijów: [SUPU].

Naulko, V. (1965). Etnichnyı̆ sklad naselennia Ukraïns'koï RSR. Kyïv: Naukova Dumka. 
Patek, A. (2011). Polska diaspora w Rosji Radzieckiej i ZSRR. W A. Walaszek (Red.), Polska diaspora (ss. 293-316). Kraków: Wydawnictwo Literackie.

Pomian, K. (2006). Historia: Nauka wobec pamięci. Lublin: Wydawnictwo Uniwersytetu Marii Skłodowskiej-Curie.

Rudnicki, S. (2000). Stopień znajomości i sfery funkcjonowania języka polskiego we wsi Nowy Zawod na południowej Żytomierszczyźnie. W W. Szulowska \& E. Wolnicz-Pawłowska (Red.), Kontakty językowe polszczyzny na pograniczu wschodnim. Warszawa: Wydawnictwo Semper.

Saryusz-Wolska, M., \& Traba, R. (2014). Modi memoranda: Leksykon kultury pamięci. Warszawa: Wydawnictwo Naukowe SCHOLAR.

Sembrzycki, J. (2002). O pochodzeniu i znaczeniu stów "Mazur" i "Mazury”. W R. Traba (Red.), Mazurzy: Tradycja i codzienność (ss. 54-59). Olsztyn: Wydawnictwo Borussia.

Serczyk, W. (2009). HistoriaUkrainy. Wrocław: Wydawnictwo Ossolineum.

Straczuk, J. (2006). Cmentarz i stót: Pogranicze prawosławno-katolickie w Polsce i na Biatorusi. Wrocław: Wydawnictwo Uniwersytetu Wrocławskiego.

Stroński, H. (1996). Deportacje polskiej ludności z Ukrainy do Kazachstanu. W S. Ciesielski\& A. Kuczyński (Red.), Polacy w Kazachstanie: Historia i współczesność (ss. 239246). Wrocław: Wydawnictwo Uniwersytetu Wrocławskiego.

Sulimierski, F., Chlebowski, B., \& Walewski, W. (Red.).(1884). Stownik Geograficzny Królestwa Polskiego i innych krajów słowiańskich (T. 5). Warszawa: Nakładem Władysława Walewskiego. Pozyskano z: http://dir.icm.edu.pl/Slownik_geograficzny/Tom_V/

Szacki, J. (2011). Tradycja. Warszawa: Wydawnictwo Uniwersytetu Warszawskiego.

Tönnies, F. (2008). Wspólnota i stowarzyszenie. Warszawa: Wydawnictwo Naukowe PWN.

Voĭnarovs'kyı̆, A. (2004). Radians'ka natsional'na polityka ta ïi vplyv na Poliakiv Podillia. W H. Stroński (Red.), Pamiętnik Kijowski: T. 7. Polacy na Podolu (ss. 181-189). Kijów: [SUPU].

Werenicz, W. (1996). Uwagi do badań nad Polskiem dialektem kresowym na Ukrainie. W J. Rieger (Red.), Język polski dawnych Kresów Wschodnich (T. 1). Warszawa: Wydawnictwo Semper.

Wolski, K. (1994). „Podole” Oskara Kolberga. W O. Kolberg, Dzieła wszystkie: T. 47. Podole (ss. III-XIV). Wrocław: Wydawnictwo Polskie Towarzystwo Ludoznawcze.

Wylęgała, A. (2015). Podzielona czy zróżnicowana?: Jeszcze raz o pamięci społecznej na Ukrainie (Z tożsamością w tle). Kultura i Społeczeństwo, 59(2), 99-116.

Zowczak, M. (2003). O długim trwaniu Polaków na Podolu: Imponderabilia tożsamości. W Ł. Smyrski \& M. Zowczak (Red.), Podole i Wotyń: Szkice etnograficzne. (ss. 9-76). Warszawa: Wydawnictwo DiG.

Zowczak, M. (2004). Modlitwa jako źródło tożsamości. W H. Stroński (Red.), Pamiętnik Kijowski: T. 7. Polacy na Podolu (ss. 219-249). Kijów: [SUPU]. 